May 2002 • NREL/CP-520-31428

\title{
Physical Properties of HWCVD Microcrystalline Silicon Thin Films
}

\section{Preprint}

H.R. Moutinho, M.J. Romero, C.-S. Jiang, Y. Xu, B.P. Nelson, K.M. Jones, A.H. Mahan, and M.M. Al-Jassim

To be presented at the $29^{\text {th }}$ IEEE PV Specialists Conference New Orleans, Louisiana May 20-24, 2002
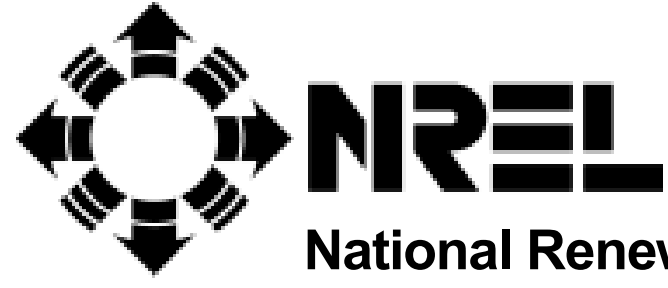

National Renewable Energy Laboratory

1617 Cole Boulevard Golden, Colorado 80401-3393

NREL is a U.S. Department of Energy Laboratory Operated by Midwest Research Institute $\bullet$ Battelle $\bullet$ Bechtel 


\section{NOTICE}

The submitted manuscript has been offered by an employee of the Midwest Research Institute (MRI), a contractor of the US Government under Contract No. DE-AC36-99G010337. Accordingly, the US Government and MRI retain a nonexclusive royalty-free license to publish or reproduce the published form of this contribution, or allow others to do so, for US Government purposes.

This report was prepared as an account of work sponsored by an agency of the United States government. Neither the United States government nor any agency thereof, nor any of their employees, makes any warranty, express or implied, or assumes any legal liability or responsibility for the accuracy, completeness, or usefulness of any information, apparatus, product, or process disclosed, or represents that its use would not infringe privately owned rights. Reference herein to any specific commercial product, process, or service by trade name, trademark, manufacturer, or otherwise does not necessarily constitute or imply its endorsement, recommendation, or favoring by the United States government or any agency thereof. The views and opinions of authors expressed herein do not necessarily state or reflect those of the United States government or any agency thereof.

Available electronically at http://www.osti.gov/bridge

Available for a processing fee to U.S. Department of Energy and its contractors, in paper, from:

U.S. Department of Energy

Office of Scientific and Technical Information

P.O. Box 62

Oak Ridge, TN 37831-0062

phone: 865.576 .8401

fax: 865.576.5728

email: reports@adonis.osti.gov

Available for sale to the public, in paper, from:

U.S. Department of Commerce

National Technical Information Service

5285 Port Royal Road

Springfield, VA 22161

phone: 800.553 .6847

fax: 703.605.6900

email: orders@ntis.fedworld.gov

online ordering: http://www.ntis.gov/ordering.htm

Printed on paper containing at least $50 \%$ wastepaper, including $20 \%$ postconsumer waste 


\title{
PHYSICAL PROPERTIES OF HWCVD MICROCRYSTALLINE SILICON THIN FILMS
}

\author{
H.R. Moutinho, M.J. Romero, C.-S. Jiang, Y. Xu, B.P. Nelson, K.M. Jones, A.H. Mahan, and M.M. Al-Jassim \\ National Renewable Energy Laboratory, 1617 Cole Blvd., Golden CO 80401
}

\begin{abstract}
S
Microcrystalline silicon films were grown with different thicknesses and different hydrogen dilution ratios on glass and Si substrates. Some films were deposited with a seed layer, whereas others were deposited directly on the substrate. We used atomic force microscopy, scanning electron microscopy, and X-ray diffraction to study the morphology and crystalline structure of the samples. We did not find a significant influence of the different substrates on the morphology or crystalline structure. The presence of the seed layer enhanced the crystallization process, decreasing the amount of amorphous layer present in the films. The microstructure of most films was formed by grains, with a subgrain structure. Films grown with low values of dilution ratio had (220) texture and elongated grains, whereas films deposited with high values of dilution ratio were randomly oriented and had an irregular shape.
\end{abstract}

\section{INTRODUCTION}

Microcrystalline $\mathrm{Si}$ ( $\mu \mathrm{c}-\mathrm{Si}$ ) has been receiving great interest lately for use in thin-film solar cells. Some attractive properties of this material are that it does not have the light-degradation problem observed in amorphous silicon (a-Si), and production costs are lower than for crystalline Si. Also, $\mu \mathrm{c}-\mathrm{Si}$ can be doped $\mathrm{p}$ - or $\mathrm{n}$ type [1,2], giving rise to complete devices [3]. Because it has a smaller bandgap than a-Si, it absorbs part of the solar spectrum that is not absorbed by this material, and can be used in a-Si/ $\mu \mathrm{c}-\mathrm{Si}$ tandem solar cells [4]. Nevertheless, before cells made with $\mu \mathrm{c}$-Si can compete with more conventional solar cells, a better understanding of how the film properties correlate with growth parameters will have to be attained, as well as a better knowledge of the physics of the devices. For this work we chose hot-wire chemical vapor deposition (HWCVD) [5] because it allows the growth of good-quality films at higher deposition rates than other techniques, such as plasmaenhanced chemical vapor deposition. We report on the influence of the ratio between $\mathrm{H}_{2}$ and $\mathrm{SiH}_{4}$ (dilution ratio) during deposition on the properties of $\mu \mathrm{c}-\mathrm{Si}$. We also investigate the influence of film thickness and substrate, crystalline Si or glass, on the material properties. This latter subject is important because it is common practice to deposit $\mu \mathrm{c}-\mathrm{Si}$ on different substrates. For instance, for $\mathrm{X}$ ray measurements the use of glass substrates may be more convenient, whereas for transmission electron microscopy the use of crystalline Si makes the process of sample preparation easier. To our knowledge, there is not much work relating the properties of this material with the use of different substrates. Furthermore, it has been shown before, for other materials, that the nucleation and growth processes can strongly depend on substrate [6]. Finally, we study the effectiveness of a Si seed layer on the early crystallization of the films.

\section{EXPERIMENTAL PROCEDURE}

The $\mu \mathrm{C}-\mathrm{Si}$ films were grown by HWCVD using two 0.5-mm-diameter tungsten filaments, kept at $13 \mathrm{~A}$ $\left(\cong 1850^{\circ} \mathrm{C}\right.$ ) each during deposition. The source of Si was silane $\left(\mathrm{SiH}_{4}\right)$, which was diluted with hydrogen $\left(\mathrm{H}_{2}\right)$. The chamber pressure was $150 \mathrm{mTorr}$, and the initial substrate temperature was $400^{\circ} \mathrm{C}$. The proximity of filaments and substrates resulted in a final substrate temperature that was $20^{\circ}-40^{\circ} \mathrm{C}$ higher than the initial temperature. The dilution ratio $\left(\mathrm{sccm} \mathrm{H} \mathrm{H}_{2} / \mathrm{sccm} \mathrm{SiH}_{4}\right.$ ) for samples deposited with a seed layer was equal to 14 , whereas for samples deposited without a seed layer it was varied from 10 to 150. The 12-nm-thick $\mu \mathrm{c}-\mathrm{Si}$ used as seed layer was grown with the following parameters: 100 dilution ratio $(R)$, $400^{\circ} \mathrm{C}$ initial substrate temperature, $150 \mathrm{mTorr}$ chamber pressure, and $13 \mathrm{~A}$ filament current. The films were deposited on 1737 Corning glass and (100) crystalline silicon, with a thickness that varied from 35 to $1700 \mathrm{~nm}$. The analytical techniques employed in this work were: atomic force microscopy (AFM), using a Digital Instruments Dimension 3100 AFM, in tapping mode, to study the surface morphology, including grain shape and size, and roughness; scanning electron microscopy (SEM), using a JEOL 6320F field-emission SEM, to complement the AFM studies on film morphology, and for thickness measurements; X-ray diffraction (XRD), using a Scintag X1 diffractometer, to study the crystalline structure of the films, including $\theta / 2 \theta$ mode, for the bulk, and grazing incidence mode $\left(5^{\circ}\right.$ to $\left.0.2^{\circ}\right)$, for regions close to the surface.

\section{RESULTS AND DISCUSSION}

\section{Atomic force microscopy}

No major differences were observed on the morphology of the $\mu \mathrm{c}-\mathrm{Si}$ films deposited on glass and $\mathrm{Si}$ substrate, including the RMS roughness values. This fact can be observed in Fig. 1. The reason for this behavior is 


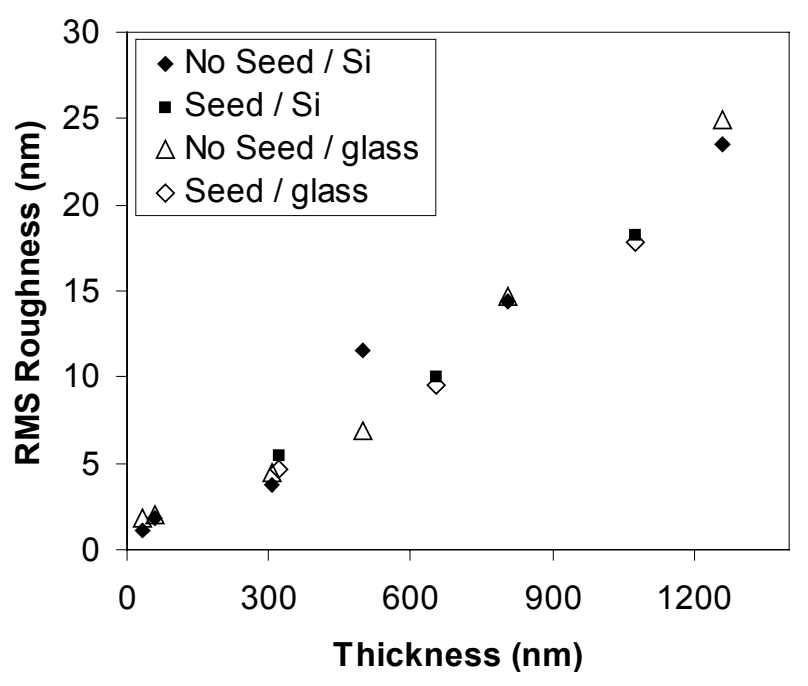

(a)

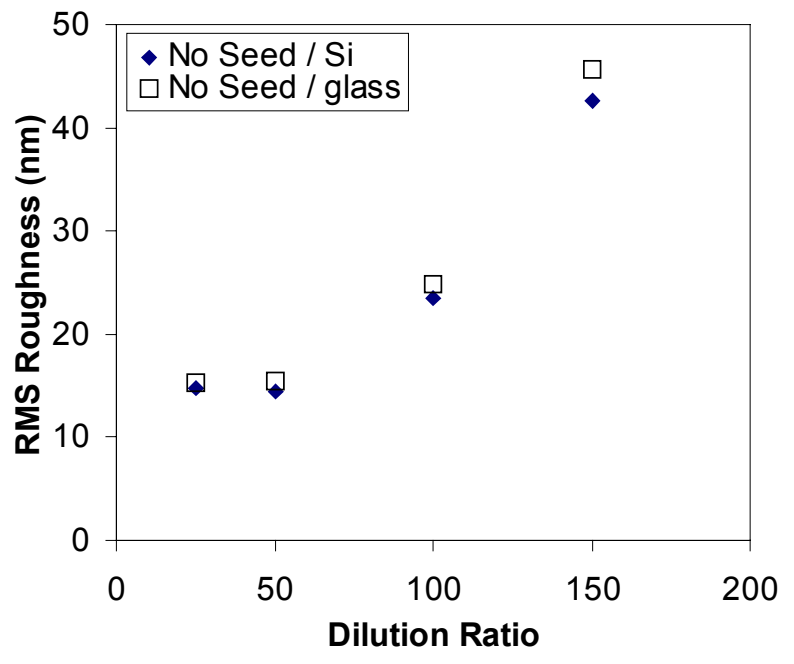

(b)

Fig. 1. Variation of RMS roughness with film thickness and dilution ratio. (a) Dilution ratio: 100 (unseeded films) and 14 (seeded films). (b) Thickness $\cong 1300 \mathrm{~nm}$.

not known at this time, but it could be caused by the presence of large quantities of hydrogen during growth, or even the condition of the surface of the Si substrate and the possible presence of a $\mathrm{SiO}_{2}$ layer. These results indicate that analysis done on $\mu \mathrm{c}-\mathrm{Si}$ deposited on glass or $\mathrm{Si}$, with the present conditions, can be compared without major concerns about the material being different.

From Fig. 1(a) we observe that there is a continuous increase in RMS roughness with thickness, which is the case for most types of thin films. The roughness is mostly caused by the microcrystalline phase (which may not be pure) on the surface, because the amorphous phase is much smoother. Fig. 2(a) shows the AFM image of a film with a mixture of amorphous and crystalline phase on the surface. The value of the roughness for the whole film, considering both phases, is $29 \mathrm{~nm}$, whereas the roughness for the amorphous phase alone is $2 \mathrm{~nm}$. An increase in $R$ also increases the

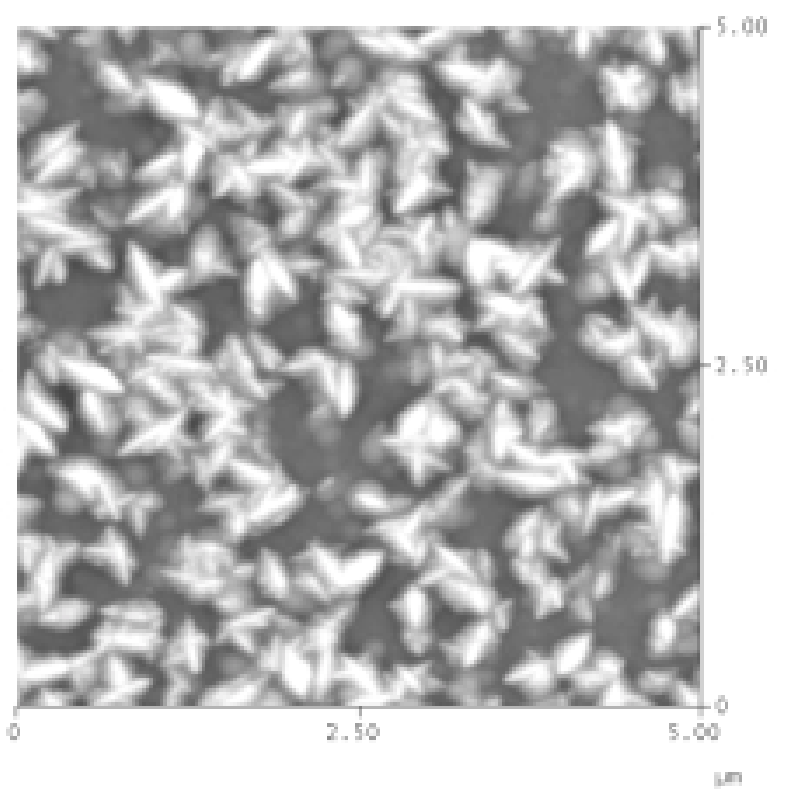

(a)

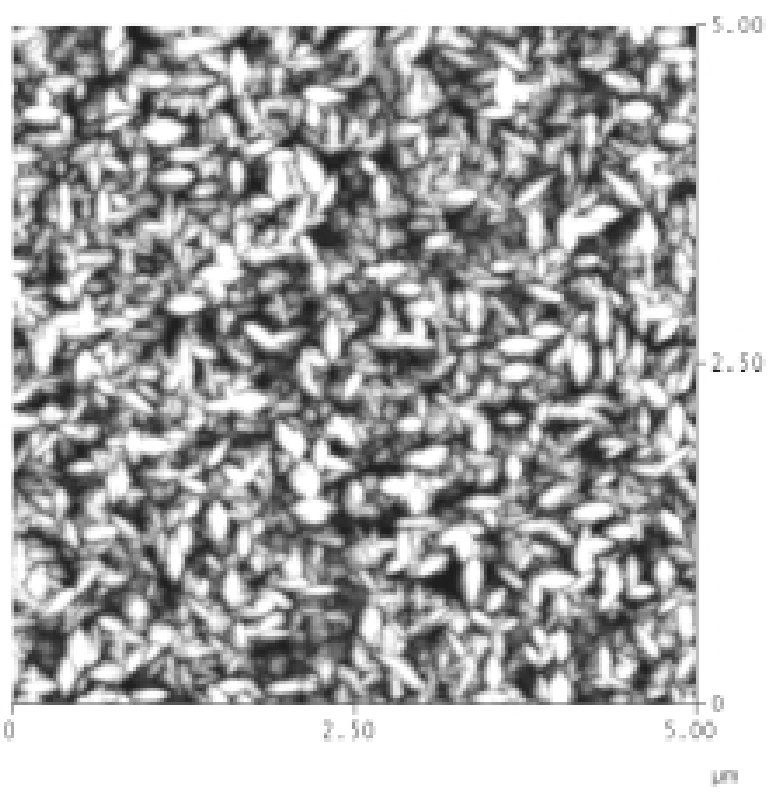

(b)

Fig. 2. AFM images of (a) 1712-nm-thick $\mu \mathrm{c}$-Si film deposited without seed layer, and (b) 1075-nm-thick $\mu \mathrm{c}-S \mathrm{film}$ deposited with seed layer. $R$ is equal to 14 for both films. 
roughness of films deposited with the same thickness, as observed in Fig. 1(b). It seems that the roughness is constant up to a value of $R$ equal to 50 , but more analysis will be necessary to confirm this. We find it interesting that the roughness values for films grown without seed layer at $R$ equal to 100 are very similar to the ones for films grown with seed layer at $\mathrm{R}$ equal to 14 . It has been observed often, for different growth conditions, that an increase in dilution ratio increases the crystallinity of the film [7]. The presence of the seed layer probably enhances the nucleation of micro-crystals, compensating for a decrease in $R$, and, hence, resulting in a similar roughness. It is important to realize that although the effect on roughness is the same, the two processes are completely different. The use of a seed layer accelerates the nucleation of the crystalline phase, whereas an increase in $R$ is related to etching of weak bonds [8], slowing down the nucleation of the amorphous phase, and decreasing the deposition rate of the film as a whole, as shown in Fig. 3. The effect of the seed layer can be observed by comparing Figs. 2(a) and 2(b). Although both films were deposited with the same value of $R$, the film deposited with a seed layer, despite being thinner, is completely covered by a crystalline phase, while the film deposited without a seed layer shows the crystalline phase surrounded by an amorphous phase. At this point, it is important to mention that AFM analyzes only the surface of the film and cannot directly confirm the crystallinity of the features observed in the images. Also, the similarity in roughness for films grown with and without seed layer at very different hydrogen concentrations does not necessarily mean that they have similar bulk crystallinity. Indeed, it is unlikely that this is the case, because hydrogen is important not only during nucleation, but also during film growth.

Seedless films deposited with a value of $R$ equal to 100 showed a change in morphology with thickness. Thinner films (up to $300 \mathrm{~nm}$ ) have round, small, grain-like features (subgrains), which start to agglomerate in larger grains for thicknesses above $500 \mathrm{~nm}$. Although the roughness and the size of the large grains increase with thickness, the subgrains do not significantly grow, as shown in Fig. 4. In the thicker films, some elongated

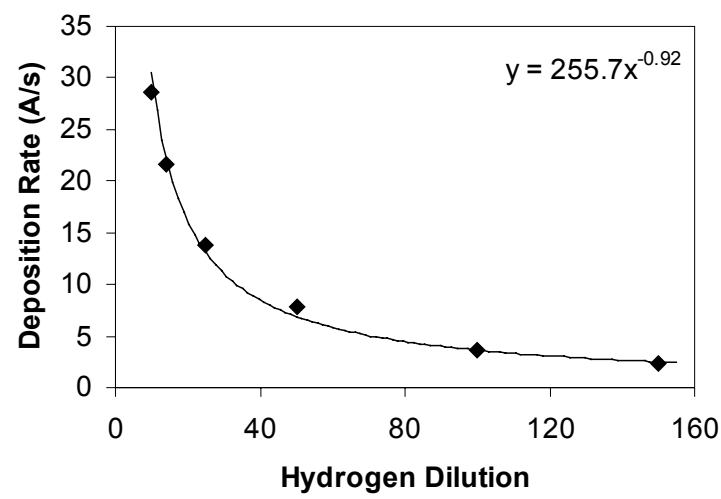

Fig. 3. Deposition rate versus hydrogen dilution ratio for $\mu \mathrm{c}$-Si films deposited without seed layer.

grains begin to appear. The increase in grain size is the main reason for the increase in roughness with thickness. For a given thickness ( $\cong 1250 \mathrm{~nm})$, a decrease in $R$ changes the grains shape from irregular to elongated (Figs. 4(b) and 4(c)). Nevertheless, both structures are still composed of smaller round subgrains, which roughly double in size as $R$ varies from 25 to 100 . As will be presented in the following, the shape of the grains is related to crystalline texture. The morphology of the films grown with seed layer also shows round subgrains, which agglomerates in larger grains for thicker films. These grains in turn grow as the thickness increases. The main difference in comparison to unseeded films is a much higher number of elongated grains, which is caused by the fact that these samples are grown with $R$ equal to 14 .

\section{X-ray diffraction}

The X-ray diffraction analysis ( $\theta-2 \theta$ mode) also showed similar results for the films deposited on $\mathrm{Si}$ and glass, which reinforces the AFM data. For this reason, and for simplicity, the grazing incidence analysis was done only on samples deposited on glass.

All the $\mu \mathrm{c}-\mathrm{Si}$ films analyzed have the cubic

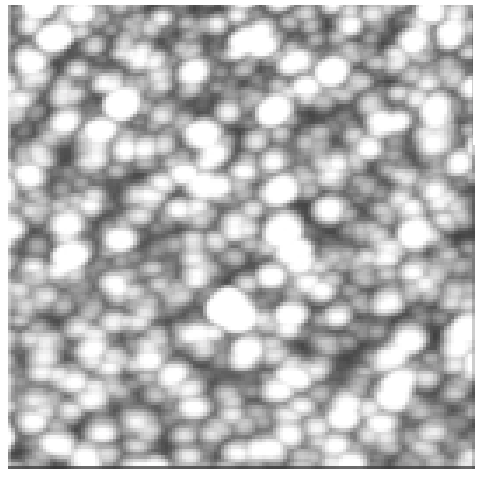

0

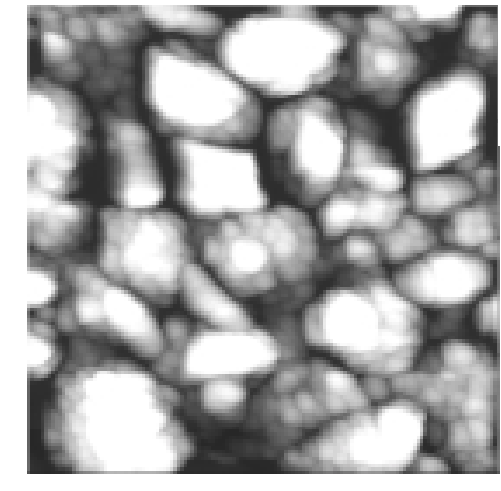

(b)

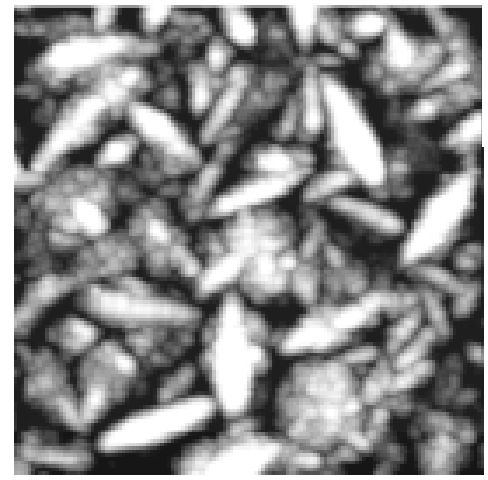

0

(c)

Fig. 4. AFM images of $\mu c-S i$ film deposited without seed layer. (a) $R=100$, thickness $=307 \mathrm{~nm}$; (b) $R=100$, thickness $=1259 \mathrm{~nm}$; (c) $\mathrm{R}=25$, thickness $=1244 \mathrm{~nm}$. 
structure (JCPDS card no. 27-1402). The films deposited without seed layer and $R$ equal to 100 did not have significant texture, and the intensity of the peaks decreased with the thickness until they disappeared for films under $60 \mathrm{~nm}$. Grazing incidence XRD (GIXRD) showed that, although weak, there were still diffraction peaks in the XRD patterns for 59- and 35-nm-thick films. A careful analysis indicated that these films are mostly crystalline for thicknesses above $300 \mathrm{~nm}$, while very thin films $(<60 \mathrm{~nm})$ seem to have a significant fraction of amorphous phase (we did not deposit films with thickness between 60 and $300 \mathrm{~nm}$ ).

The XRD patterns of seedless films deposited with varying $R$ is shown in Fig. 5. The film deposited with $R$ equal to 10 is mostly amorphous, which is confirmed by the AFM analysis. For $\mathrm{R}$ equal to 14 there is a striking change, and the film shows a crystalline phase with strong (220) texture. The texture is still present for $R$ equal to 25, but to a lesser extent. Films grown with $\mathrm{R}$ equal to 50 and 100 are randomly oriented. A comparison of these results with the AFM data revealed that films with elongated-grain morphology (Fig. 2) have strong (220) texture, films with irregular-shape grain morphology (Fig. 4b) are randomly oriented, and films with mixed morphology (Fig. 4c) have a not-so-strong (220) texture. These results indicate that $R$ is the most important factor controlling the crystalline properties of the films.

Our analysis of the seeded films, all of them deposited with $\mathrm{R}$ equal to 14 , confirmed the previous findings, because all the films had (220) texture.

With the growth parameters used in this work, most films had enough crystalline material to provide diffraction peaks with reasonable intensity. A comparison between diffraction patterns of films deposited with and without seed layer ( $R$ equal to 14 and 100 , respectively) indicated that the latter films have a larger fraction of crystalline phase, implying that the use of a seed layer may not be as effective as the AFM measurements may suggest. Although these techniques are not appropriate for this kind of analysis, preliminary results of Raman spectroscopy measurements corroborate these results. Raman spectroscopy and transmission electron microscopy are being used to study the crystallinity of these films, and the results will be published shortly.

\section{CONCLUSIONS}

The use of a very thin seed layer promotes the early deposition of a crystalline phase in $\mu \mathrm{c}-\mathrm{Si}$ films, decreasing the amount of amorphous material present in the film. The morphology and crystalline structure of the films are mostly controlled by the dilution ratio. Low values of $R$ result in films with (220) texture and elongated grains, whereas large values of $R$ result in randomly oriented films with irregular-shaped grains. The size of the grains, as well as film roughness, increases with thickness, and the grains are formed by a structure of subgrains. No significant differences were found on the properties of films grown on glass or Si substrates for the parameters used in this work.

\section{ACKNOWLEDGEMENTS}

The authors would like to thank David Albin for his help in the interpretation of the GIXRD data. This work was supported by the U.S. Department of Energy under contract number DE-AC36-99G010337.

\section{REFERENCES}

[1] J. Puigdollers, J. Cifre, M.C. Polo, J.M. Asensi, J. Tertomeu, J. Andreu, and A. Lloret, Appl. Suf. Sci. 86, 1995, pp. 600-603.

[2] S.C. Saha, J.K. Rath, S.T. Kshirsagar, and S. Ray, J. Phys. D: Appl. Phys. 30, 1997, pp. 2686-2692.

[3] J. Meier, E. Vallat-Sauvain, S. Dubail, U. Kroll, J. Dubail, S. Golay, L. Feitknecht, P. Torres, S. Fay, D. Fishcher, and A. Shah, Sol. En. Mat. \& Sol. Cells 66, 2001, pp. 73-84.

[4] Y. Hamakawa and H. Takakura, Proc. Twenty-Eighth IEEE PVSC, 2000, pp. 766-771.

[5] M. Konagai, T. Tsushima, Y. Ide, K. Asakusa, T. Jujisaki, M.K. Kim, Y, Wakita and A. Yamada, Proc. Twenty-Eighth IEEE PVSC, 2000, pp. 788-791.

[6] H.R. Moutinho, R.G. Dhere, K. Ramanathan, P. Sheldon, and L.L. Kazmerski, Proc. Twenty-Fifth IEEE PVSC, 1996, pp. 945-948.

[7] C. Niikura, J. Guillet, R. Brenot, B. Equer, J.E. Bouree, C. Voz, D. Peiro, J.M. Asensi, J. Bertomeu, and J. Andreu, J. Non-Cryst. Sol. 266, 2000, 385-390.

[8] P. Roca i Cabarrocas and S. Hamma, Thin Solid Films 337, 1999, pp. 23-26.

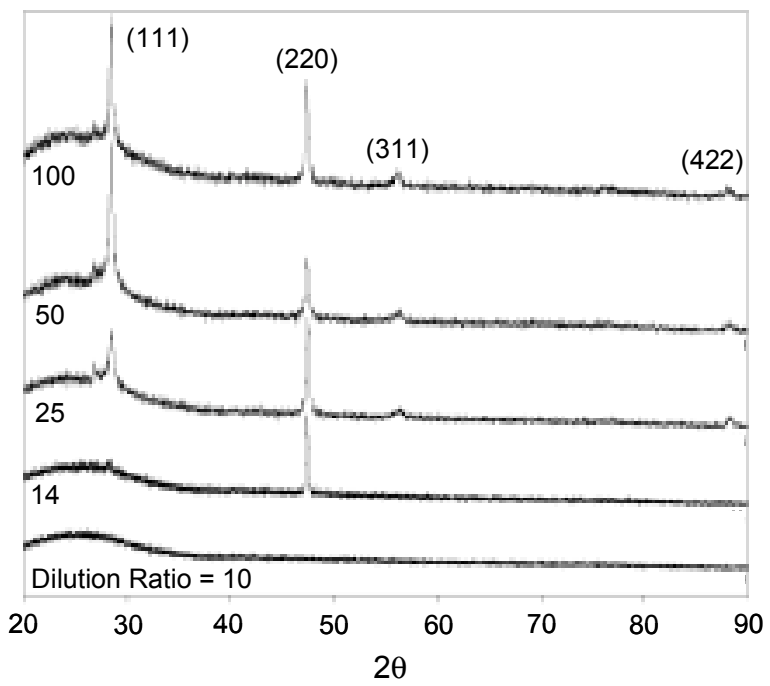

Fig. 5. X-ray diffraction patterns for seedless $\mu \mathrm{c}-\mathrm{Si}$ deposited with different dilution ratios. 


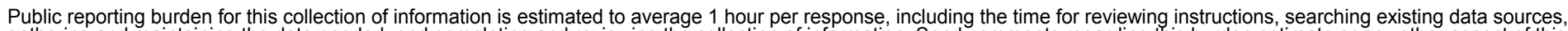

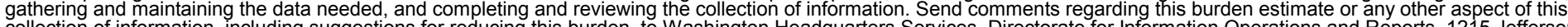
Davis Highway, Suite 1204, Arlington, VA 22202-4302, and to the Office of Management and Budget, Paperwork Reduction Project (0704-0188), Washington, DC 20503.

\begin{tabular}{|l|l|l|}
\hline 1. AGENCY USE ONLY (Leave blank) & $\begin{array}{l}\text { 2. REPORT DATE } \\
\text { May } 2002\end{array}$ & $\begin{array}{l}\text { 3. REPORT TYPE AND DATES COVERED } \\
29^{\text {th }} \\
\text { IEEE PVSC-Conference Paper } \\
\text { May 20-24 2002 }\end{array}$ \\
\hline
\end{tabular}

4. TITLE AND SUBTITLE Physical Properties of HWCVD Microcrystalline Silicon Thin Films: Preprint

6. $\operatorname{AUTHOR}(\mathrm{S})$

H.R. Moutinho, M.J. Romero, C.-S. Jiang, Y. Xu, B.P. Nelson, K.M. Jones, A.H. Mahan, and M.M. Al-Jassim

7. PERFORMING ORGANIZATION NAME(S) AND ADDRESS(ES) National Renewable Energy Laboratory

1617 Cole Blvd.

Golden, CO 80401-3393

9. SPONSORING/MONITORING AGENCY NAME(S) AND ADDRESS(ES)

National Renewable Energy Laboratory

1617 Cole Blvd.

Golden, CO 80401-3393
5. FUNDING NUMBERS PVP23201

8. PERFORMING ORGANIZATION REPORT NUMBER

11. SUPPLEMENTARY NOTES

12a. DISTRIBUTION/AVAILABILITY STATEMENT

National Technical Information Service

U.S. Department of Commerce

5285 Port Royal Road

Springfield, VA 22161

13. ABSTRACT (Maximum 200 words): This conference paper describes Microcrystalline silicon films were grown with different thicknesses and different hydrogen dilution ratios on glass and Si substrates. Some films were deposited with a seed layer, whereas others were deposited directly on the substrate. We used atomic force microscopy, scanning electron microscopy, and X-ray diffraction to study the morphology and crystalline structure of the samples. We did not find a significant influence of the different substrates on the morphology or crystalline structure. The presence of the seed layer enhanced the crystallization process, decreasing the amount of amorphous layer present in the films. The microstructure of most films was formed by grains, with a subgrain structure. Films grown with low values of dilution ratio had (220) texture and elongated grains, whereas films deposited with high values of dilution ratio were randomly oriented and had an irregular shape.

14. SUBJECT TERMS: PV; scanning electron microscopy (SEM); atomic force microscopy; X-ray diffraction; Raman spectroscopy; transmission electron microscopy; glass substrates;

15. NUMBER OF PAGES

16. PRICE CODE

17. SECURITY CLASSIFICATION OF REPORT

Unclassified
18. SECURITY CLASSIFICATION OF THIS PAGE Unclassified
19. SECURITY CLASSIFICATION OF ABSTRACT

Unclassified
20. LIMITATION OF ABSTRACT

UL 